\title{
Metallic vs plastic stents to treat biliary stricture after liver transplantation: a systematic review and meta-analysis based on randomized trials
}

\section{(ㄷ)(우우}

\author{
Authors \\ Thiago Arantes de Carvalho Visconti, Wanderley Marques Bernardo, Diogo Turiani Hourneaux Moura, Eduardo \\ Turiani Hourneaux Moura, Caio Vinicius Tranquillini Gonçalves, Galileu Ferreira Farias, Hugo Gonçalo Guedes, Igor \\ Braga Ribeiro, Tomazo Prince Franzini, Gustavo Oliveira Luz, Marcos Eduardo dos Lera dos Santos, Eduardo \\ Guimarães Hourneaux de Moura
}

\author{
Institution \\ Department of Gastroenterology, Hospital das Clinicas \\ from University of São Paulo Medical School, São Paulo, \\ Brazil
}

submitted 16.1.2018

accepted after revision 25.4.2018

\author{
Bibliography \\ DOI https://doi.org/10.1055/a-0626-7048 | \\ Endoscopy International Open 2018; 06: E914-E923 \\ (c) Georg Thieme Verlag KG Stuttgart · New York \\ ISSN 2364-3722
}

\section{Corresponding author}

Thiago A. de C. Visconti, MD, Rua José de Magalhães, 373, apartment 1404, São Paulo - SP, Brazil

thiago.visconti@yahoo.com.br

\section{ABSTRACT}

Background and study aims The first-line approach to anastomotic biliary stricture after orthotopic liver transplantation (OLTX) involves endoscopic retrograde cholangiopancreatography (ERCP). The most widely used technique is placement of multiple plastic stents, but discus- sions are ongoing on the benefits of fully-covered self-expandable metallic stents (FCEMS) in this situation. This study aimed to compare results from use of plastic and metal stents to treat biliary stricture after transplantation. Patients and methods Searches were performed in the Medline, EMBASE, SciELO/LILACS, and Cochrane databases, and only randomized studies comparing the two techniques were included in the meta-analysis.

Results Our study included four randomized clinical trials totaling 205 patients. No difference was observed between the stricture resolution rate (RD: $0.01 ; 95 \% \mathrm{Cl}$ $[-0.08-0.10]$ ), stricture recurrence (RD: $0.13 ; 95 \% \mathrm{Cl}$ $[-0.03-0.28]$ ), and adverse events (RD: $-0.10 ; 95 \% \mathrm{Cl}$ $[-0.65-0.44])$ between the plastic and metallic stent groups. The metallic stent group demonstrated benefits in relation to the number of ERCPs performed (MD: -1.86; $95 \% \mathrm{Cl}[-3.12$ to -0.6$]$ ), duration of treatment (MD: $-105.07 ; 95 \% \mathrm{Cl}$ [ -202.38 to -7.76 days]), number of stents used (MD: $-10.633 ; 95 \% \mathrm{Cl}[-20.82$ to -0.44$])$, and cost (average $\$ 8,288.50$ versus $\$ 18,580.00, P<0.001$ ).

Conclusions Rates of resolution and recurrence of stricture are similar, whereas the number of ERCPs performed, number of stents used, duration of treatment, and costs were lower in patients treated with FCEMS, which shows that this device is a valid option for initial treatment of post-OLTX biliary stricture.

\section{Introduction}

Anastomotic biliary stricture is the most common adverse event (AE) after orthotopic liver transplantation (OLTX), occurring in $5 \%$ to $19 \%$ of patients [ $1-5]$. The first-line approach to this type of stricture involves endoscopic retrograde cholangiopancreatography (ERCP), with placement of multiple plastic stents (MPSs) [6-9]. However, the benefits of using fully-covered self-expandable metallic stents (CSEMS) in this situation are still being discussed [10-12]. The most significant drawback of using MPS is the number of ERCPs needed to complete the treatment because the plastic stents have to be replaced approximately every 3 months; the number and diameter of the stents is increased until the stricture is resolved $[7,13]$.

CSEMS have been used to treat benign strictures with encouraging results because their removal is no longer a limiting factor [10]. The initial premise is that only two ERCPs are needed to treat the biliary anastomotic stricture after OLTX: one to place the metallic stent and another to remove it, leading to greater acceptance by patients and potentially lesser costs and fewer AEs [13]. Case series with CSEMS have already demonstrated the safety of these devices, and few studies on this topic 
have shown similar rates of treatment success, recurrence, and AEs between the two types of treatment [14-17].

Therefore, the current systematic review and meta-analysis evaluates all the randomized studies available in the literature to compare use of MPS and CSEMS with regard to efficacy, safety, and cost in treating anastomotic biliary stricture after liver transplantation.

\section{Patients and methods}

This systematic review and meta-analysis were performed according to the recommendations of Preferred Reporting Items for Systematic Reviews and Meta-Analyses and registered in the international PROSPERO database (CRD 42017068478) [18].

\section{Eligibility criteria}

Only randomized clinical trials (RCTs) comparing use of MPS with CSEMS in initial treatment of anastomotic biliary stricture after liver transplantation were included. There were no restrictions with regard to language. Inclusion criteria were patients aged $>18$ who underwent OLTX and had stricture of the biliary anastomosis confirmed via cholangiography. Exclusion criteria were recurrent biliary stricture, non-anastomosis biliary stricture, and stricture in the hepatic hilum.

\section{Search and selection of articles and collection of data}

Two independent researchers conducted the search, evaluated and selected the articles; disagreements were resolved by consensus. Databases searched were Medline (PubMed), EMBASE, SciELO/LILACS, and Cochrane until October 2017. The search strategy in Medline and EMBASE was "(Liver transplantation OR Hepatic Transplantation OR Liver Grafting OR Hepatic Transplantation) AND (biliary stricture OR biliary stenosis OR biliary stenose OR ERCP OR plastic OR metallic OR stent OR cholangiography OR cholangiopancreatography)". The search strategy in SCiELO/LILACS and Cochrane was "Liver transplantation AND biliary".

Outcomes evaluated were as follows: number of ERCPs performed, rate of stricture resolution, rate of stricture recurrence, total treatment time, stent migration, cost, AEs, and number of stents.

\section{Risk of bias}

Studies were individually evaluated with regard to proper randomization, allocation concealment, number of losses below $20 \%$, relevant outcomes, presence of analysis by intention to treat, risk bias table (RoB) tool recommended by Cochrane and Jadad scale $[19,20]$. The RoB tool assists in measuring biases through evaluation of blinding, randomization, and information on losses. Scores on Jadad scale range from 0 to 5 , with scores below 3 generally considered to represent studies of low methodological quality. Evidence quality was analyzed according to the Grading of Recommendations Assessment, Development and Evaluation Working Group (GRADE) [21].

\section{Statistical measures and analysis}

Dichotomous variables were analyzed using risk difference and Mantel-Haenszel test, whereas continuous variables were analyzed using mean difference and inverse variance. The fixed effect model was preferred, but we used the random effect model when less than $50 \%$ heterogeneity was not reached.

When studies reported medians and ranges, these were transformed into mean and standard deviations using the formula by Hozo et al. [22].

We used a $95 \%$ confidence interval, and heterogeneity was calculated using the method by Higgins (I-square).

Statistical analyses were performed with the RevMan 5 (Review Manager Version 5.3.5, Cochrane Collaboration, London, UK) and OpenEpi (Open Source Epidemiologic Statistics for Public Health) software. The relationship between sample size and effect for each outcome was graphically analyzed using a forest plot. Funnel plots were used to assess risk of publication bias or inconsistency between the study outcomes.

For cost analysis, it was necessary to convert the data from one study from Australian dollars to US dollars [13]. The exchange rate for the month of publication was used (January 2014). Then, we calculated the mean and standard deviation to perform the Student's $t$-test.

Treatment times expressed in months were converted to days.

\section{Results}

\section{Search}

The literature search yielded 3,322 articles in Medline/PubMed, 2,447 in EMBASE, 127 in SCiELO/LILACS, and 55 in Cochrane, totaling 5,951 articles. After repeated articles were excluded, 4,650 studies remained. Among these, four RCTs were found that met the inclusion criteria and were included in the meta-analysis, with a total of 205 patients (103 in the CSEMS group and 102 in the MPS group). The article selection process is illustrated in > Fig. 1.

The four selected studies have similar characteristics ( $\triangleright$ Table 1) $[10,13,23,24]$. CSEMS dwelling time ranged from 3 to 6 months and the interval to replace the plastic stents ranged from 6 to 16 weeks. The study by Kaffes et al. [6] was the only one that used metallic prostheses with greater diameter at the ends and did not mention minimum follow-up time; the other three studies $[10,23,24]$ reported follow-up of at least 1 year. Data were extracted from published material and there was no need to access original data from the studies.

\section{Biases and evidence quality}

Risks of individual biases of the four studies were restricted to double blinding, which was not possible because of the need to evaluate the stricture when the stents are placed and removed by the physician. In all studies, losses were less than $20 \%$ and randomization, appropriate allocation, and analysis by intention to treat were performed; consequently, their Jadad score was 3 ( $>$ Table 2 ). $>$ Fig. 2 shows the RoB tool recommen- 


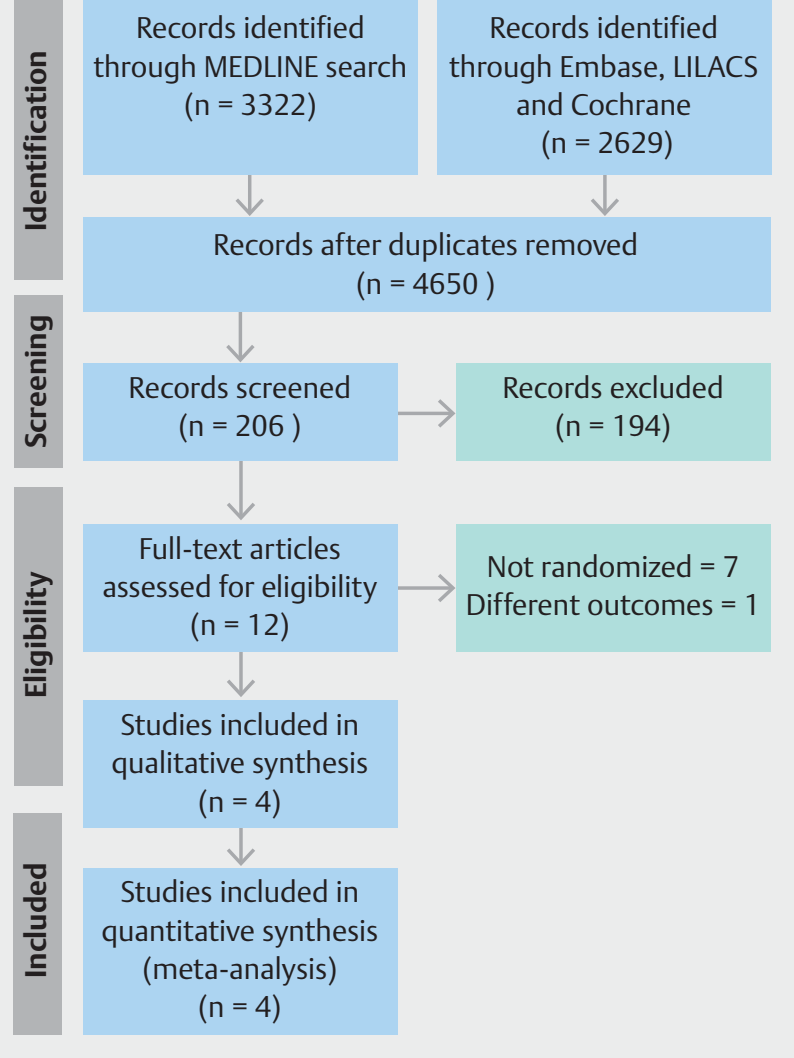

ded by Cochrane. The GRADE Summary of Findings for evidence quality can be found in $>$ Annex $\mathbf{2}$.

\section{Outcomes}

We were able to compare several outcomes, such as number of ERCPs performed, stricture resolution, stricture recurrence, treatment time, migration, AEs, costs, and number of stents ( $\triangleright$ Annex 3). Tal et al. [11] considered the result after the required crossovers (four in the CSEMS and three in the MPS groups), whereas Martins et al. [13] considered a failure when crossover was necessary. Because the number of crossovers was similar and they all resulted in stricture resolution, we agreed with the assessment by Tal et al. [11] to consider these as successful cases.

\section{Number of ERCPS performed}

The four studies were included in the analysis of the number of ERCPs performed, with a total of 205 patients. The number of ERCPs necessary for treatment was lower (MD: -1.86 ; $95 \% \mathrm{Cl}$ [ -3.12 to -0.6$])$ in the patients in whom CSEMS were used. Heterogeneity observed in the analysis exceeded $50 \%$, and funnel plot was used; no outliers were identified, and treatment heterogeneity was not possible; therefore, we used the random effect model for analysis ( $\bullet$ Fig. $\mathbf{3}$ ).

- Fig. 1 Article selection process.

- Table 1 Study characteristics.

\begin{tabular}{|c|c|c|c|c|c|c|c|c|c|}
\hline Study & $\mathbf{P}$ & I & C & Follow-up & $\begin{array}{l}\text { Metallic } \\
\text { stent } \\
\text { time }\end{array}$ & $\begin{array}{l}\text { Plastic } \\
\text { stent } \\
\text { exchange } \\
\text { time }\end{array}$ & $\begin{array}{l}\text { Plastic stents } \\
\text { total time }\end{array}$ & $\begin{array}{l}\text { Metallic stent } \\
\text { characteristics }\end{array}$ & $\begin{array}{l}\text { Stricture } \\
\text { dilation }\end{array}$ \\
\hline $\begin{array}{l}\text { Kaffes A, } \\
2014\end{array}$ & 20 & 10 & 10 & $\begin{array}{l}26(6- \\
40) / 25.5 \\
(3.0-44) \\
\text { months }\end{array}$ & 3 months & 3 months & $\begin{array}{l}\text { Up to } 12 \text { months } \\
\text { (earlier if stric- } \\
\text { ture resolution } \\
\text { were observed) }\end{array}$ & $\begin{array}{l}\text { Taewoong Medical } \\
\text { (10-mm diameter } \\
\text { at either end and } 8 \text { - } \\
\text { mm at the center) }\end{array}$ & $\begin{array}{l}\text { Endoscopist dis- } \\
\text { cretion }\end{array}$ \\
\hline $\begin{array}{l}\text { Cote GA, } \\
2016\end{array}$ & 73 & 37 & 36 & $\begin{array}{l}\text { At least } \\
1 \text { year }\end{array}$ & 6 months & $\begin{array}{l}3-4 \\
\text { months }\end{array}$ & $\begin{array}{l}\text { Up to } 12 \text { months } \\
\text { (earlier if stric- } \\
\text { ture resolution } \\
\text { were observed) }\end{array}$ & $\begin{array}{l}\text { Wallflex, Boston } \\
\text { Scientific, 8- or } \\
\text { 10-mm diameter }\end{array}$ & $\begin{array}{l}\text { Dilated all pa- } \\
\text { tients from the } \\
\text { plastic stent } \\
\text { group and at } \\
\text { endoscopist dis- } \\
\text { cretion at metal- } \\
\text { lic stent group }\end{array}$ \\
\hline $\begin{array}{l}\text { Tal AO, } \\
2017\end{array}$ & 48 & 24 & 24 & $\begin{array}{l}\text { At least } \\
1 \text { year }\end{array}$ & $\begin{array}{l}4-6 \\
\text { months }\end{array}$ & $6-12$ weeks & No information & $\begin{array}{l}\text { 10-mm diameter, } \\
\text { no anti-migration } \\
\text { flaps }\end{array}$ & $\begin{array}{l}\text { Endoscopist dis- } \\
\text { cretion }\end{array}$ \\
\hline $\begin{array}{l}\text { Martins FP, } \\
2017\end{array}$ & 64 & 32 & 32 & $\begin{array}{l}\text { At least } \\
1 \text { year }\end{array}$ & 6 months & 3 months & 12 months & $\begin{array}{l}\text { Wallflex, Boston } \\
\text { Scientific, } 10 \text {-mm } \\
\text { diameter, } 60 \text { - or } \\
80 \text {-mm length }\end{array}$ & $\begin{array}{l}\text { Dilated all pa- } \\
\text { tients from the } \\
\text { plastic stent } \\
\text { group and at } \\
\text { endoscopist dis- } \\
\text { cretion at metal- } \\
\text { lic stent group }\end{array}$ \\
\hline
\end{tabular}

P: population; I: intervention; C: control 
- Table 2 Risk of bias and Jadad.

\begin{tabular}{|c|c|c|c|c|c|c|c|c|c|c|}
\hline Study & $\begin{array}{l}\text { Focal } \\
\text { ques- } \\
\text { tion }\end{array}$ & $\begin{array}{l}\text { Appropri- } \\
\text { ate rando- } \\
\text { mization }\end{array}$ & $\begin{array}{l}\text { Alloca- } \\
\text { tion con- } \\
\text { cealment }\end{array}$ & $\begin{array}{l}\text { Double } \\
\text { blind- } \\
\text { ing }\end{array}$ & $\begin{array}{l}\text { Losts } \\
(<20 \%)\end{array}$ & $\begin{array}{l}\text { Prognosis } \\
\text { character- } \\
\text { istics }\end{array}$ & $\begin{array}{l}\text { Out- } \\
\text { comes }\end{array}$ & $\begin{array}{l}\text { Inten- } \\
\text { tion to } \\
\text { treat } \\
\text { analy- } \\
\text { sis }\end{array}$ & $\begin{array}{l}\text { Sample } \\
\text { size deter- } \\
\text { mination }\end{array}$ & Jadad \\
\hline Kaffes 2014 & Yes & Yes & Yes & No & Yes (0\%) & Yes & Yes & Yes & No & 3 \\
\hline Cote 2016 & Yes & Yes & Yes & No & Yes (8\%) & Yes & Yes & Yes & Yes & 3 \\
\hline Tal 2017 & Yes & Yes & Yes & No & Yes (17\%) & Yes & Yes & Yes & Yes & 3 \\
\hline Martins 2017 & Yes & Yes & Yes & No & Yes $(7,8 \%)$ & Yes & Yes & Yes & Yes & 3 \\
\hline
\end{tabular}

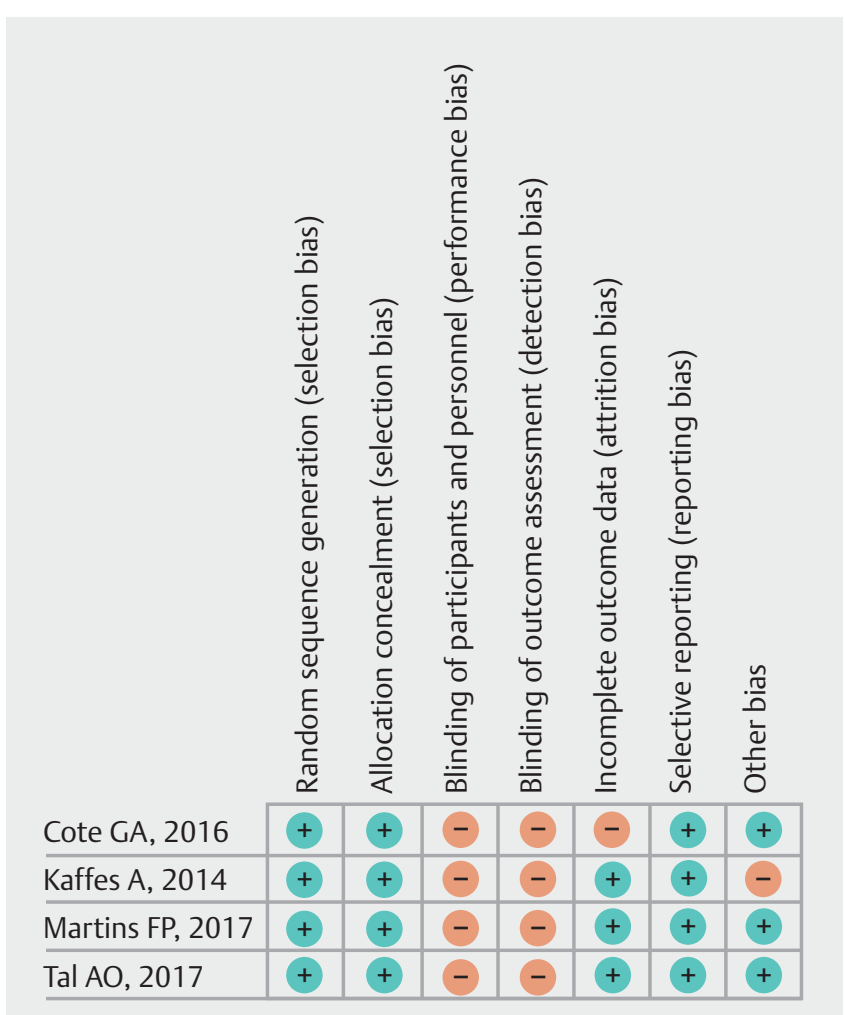

Fig. 2 Risk of bias tool.

\section{Number of stents per patient}

The number of stents per patient was lower (MD: $-10.633 ; 95 \%$ $\mathrm{Cl}[-20.82$ to -0.44$])$ in the patients in whom CSEMS were used. Heterogeneity observed in the analysis exceeded $50 \%$, and because only two studies were involved, treatment heterogeneity was not possible and it was necessary to use the random effect model for the analysis ( $>$ Fig. 4 ).

\section{Stricture resolution}

Four studies were included in analysis of the stricture resolution, with a total of 205 patients. There was no statistically significant difference in the rate of stricture resolution between the two groups, which showed equivalence for the initial suc- cess of the treatment (RD: $0.01 ; 95 \% \mathrm{Cl}[-0.08-0.10]$ ) ( Fig.5).

\section{Stricture recurrence}

No statistically significant difference was found between the two groups in evaluation of the rate of recurrence in $181 \mathrm{pa}$ tients who had successful initial stricture treatment (RD: 0.13; $95 \% \mathrm{Cl}[-0.03$ to 0.28$])$. The heterogeneity observed in the analysis exceeded $50 \%$, and funnel plot was used; no outliers were identified and treatment heterogeneity was not possible; therefore, we used the random effect model for the analysis ( Fig.6).

\section{Treatment time}

Treatment time (number of days until all stents were removed) was less in the CSEMS group (MD: $-105.07 ; 95 \% \mathrm{Cl}[-202.38$ to -7.76 days]). Heterogeneity observed in the analysis exceeded $50 \%$, and funnel plot was used; no outliers were identified and heterogeneity correction was not possible; therefore, the random effect model was used for the analysis ( $>$ Fig. 7).

\section{Adverse events}

Two studies were used in the analysis of AEs not related to migration, with a total of 84 patients. No statistically significant difference was observed (RD: $-0.10 ; 95 \% \mathrm{Cl}[-0.65$ to 0.44$]$ ). Heterogeneity observed in the analysis was greater than $50 \%$, and the random effect model was used for the analysis (> Fig.8).

Stent migration was individually analyzed and involved two studies with a total of 84 patients. Again, this analysis did not demonstrate a statistically significant difference between the materials (RD: $-0.05 ; 95 \% \mathrm{Cl}[-0.18$ to 0.08$]$ ).

\section{Cost}

Assessment of treatment cost included two studies [13,24] that reported the average cost of each treatment. Treatment with CSEMS was less expensive than that with MPS (average of $\$ 8,288.00$ and $\$ 18,580.00$, respectively; $P<0.001$ ) ( Fig. 9). 


\begin{tabular}{|c|c|c|c|c|c|c|c|c|c|c|c|}
\hline \multirow{3}{*}{$\begin{array}{l}\text { Study or subgroup } \\
\text { Cote GA, } 2016\end{array}$} & \multicolumn{3}{|c|}{ cSEMS } & \multicolumn{3}{|c|}{ MPS } & \multirow[b]{2}{*}{ Weight } & \multirow{2}{*}{$\begin{array}{l}\text { Mean difference } \\
\text { IV, random, 95\% CI }\end{array}$} & & \multirow{2}{*}{\multicolumn{2}{|c|}{$\begin{array}{l}\text { Mean difference } \\
\text { IV, random, } 95 \% \mathrm{CI}\end{array}$}} \\
\hline & Mean & SD & Total & Mean & SD & Total & & & & & \\
\hline & 2.21 & 0.48 & 37 & 3.13 & 0.88 & 36 & $26.8 \%$ & $-0.92[-1.25,-0.59]$ & & \multirow[t]{3}{*}{$\rightarrow-$} & \\
\hline Kaffes A, 2014 & 2 & 0.20 & 10 & 4.25 & 1.1 & 10 & $25.2 \%$ & $-2.25[-2.94,-1.56]$ & \multirow{2}{*}{$\longrightarrow$} & & \\
\hline Martins FP, 2017 & 2 & 0.0001 & 32 & 4.9 & 0.6 & 32 & $27.1 \%$ & $-2.90[-3.11,-2.69]$ & & & \\
\hline Tal AO, 2017 & 4.5 & 2.5 & 24 & 5.75 & 2.25 & 24 & $20.8 \%$ & $-1.25[-2.60,0.10]$ & & & \\
\hline Total (95\% CI) & & & 103 & & & 102 & $100.0 \%$ & $-1.86[-3.12,-0.60]$ & & & \\
\hline $\begin{array}{l}\text { Heterogeneity: } \mathrm{Tau}^{2} \\
\text { Test for overall effect }\end{array}$ & $\begin{array}{l}=1.51 \\
: Z=2.9\end{array}$ & $\begin{array}{l}C h i^{2}=10 \\
O(P=0 .\end{array}$ & $\begin{array}{l}3.01, d \\
004)\end{array}$ & $3(P=c$ & .0000 & $; I^{2}=9$ & & & $\begin{array}{c}-2 \\
\text { Favors }\end{array}$ & $\begin{array}{l}-1 \\
\text { [CSEMS] }\end{array}$ & $\begin{array}{rrr}0 & 1 & 2 \\
& \text { Favors [MPS] }\end{array}$ \\
\hline
\end{tabular}

Fig. 3 Forest Plot of number of ERCPs performed.

\begin{tabular}{|c|c|c|c|c|c|c|c|c|c|c|c|c|}
\hline \multirow{3}{*}{$\begin{array}{l}\text { Study or subgroup } \\
\text { Martins FP, } 2017\end{array}$} & \multicolumn{3}{|c|}{ CSEMS } & \multicolumn{3}{|c|}{ MPS } & \multirow[b]{2}{*}{ Weight } & \multirow{2}{*}{$\begin{array}{l}\text { Mean difference } \\
\text { IV, random, } 95 \% \mathrm{CI}\end{array}$} & \multirow{2}{*}{\multicolumn{4}{|c|}{$\begin{array}{l}\text { Mean difference } \\
\text { IV, random, } 95 \% \mathrm{CI}\end{array}$}} \\
\hline & Mean & SD & Total & Mean & SD & Total & & & & & & \\
\hline & 1 & 0.0001 & 32 & 16.7 & 5.6 & 32 & $51.3 \%$ & $-15.70[-17.64,-13.76]$ & \multirow{2}{*}{-1} & \multirow{2}{*}{-1} & & \\
\hline Tal AO, 2017 & 6.7 & 5.75 & 24 & 12.0 & 7.5 & 24 & $48.7 \%$ & $-5.30[-9.08,-1.52]$ & & & & \\
\hline Total $(95 \% \mathrm{Cl})$ & & & 56 & & & 56 & $100.0 \%$ & $-10.63[-20.82,-0.44]$ & & & & \\
\hline \multicolumn{9}{|c|}{ Heterogeneity: $\mathrm{Tau}^{2}=51.73 ; \mathrm{Chi}^{2}=23.01, \mathrm{df}=1(P=0.00001) ; \mathrm{I}^{2}=96 \%$} & -20 & $\begin{array}{c}-10 \\
\text { Favors [cSEMS] }\end{array}$ & $\begin{array}{lc}0 & 10 \\
\text { Favors [MPS] }\end{array}$ & 20 \\
\hline
\end{tabular}

- Fig. 4 Forest Plot of number of stents per patient.

\begin{tabular}{|c|c|c|c|c|c|c|c|}
\hline \multirow[b]{2}{*}{ Study or subgroup } & \multicolumn{2}{|c|}{ CSEMS } & \multicolumn{2}{|c|}{ MPS } & \multirow[b]{2}{*}{ Weight } & \multirow{2}{*}{$\begin{array}{l}\text { Risk difference } \\
\text { M-H, fixed, 95\% Cl }\end{array}$} & \multirow{2}{*}{$\begin{array}{c}\text { Risk difference } \\
\text { M-H, fixed, 95\% Cl }\end{array}$} \\
\hline & Events & Total & Events & Total & & & \\
\hline Cote GA, 2016 & 33 & 37 & 31 & 36 & $35.6 \%$ & $0.03[-0.12,0.18]$ & + \\
\hline Kaffes A, 2014 & 10 & 10 & 8 & 10 & $9.8 \%$ & $0.20[-0.08,0.48]$ & \\
\hline Martins FP, 2017 & 25 & 32 & 28 & 32 & $31.2 \%$ & $-0.09[-0.28,0.09]$ & 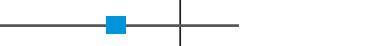 \\
\hline Tal AO, 2017 & 24 & 24 & 23 & 24 & $23.4 \%$ & $0.04[-0.07,0.15]$ & - \\
\hline Total $(95 \% \mathrm{Cl})$ & & 103 & & 102 & $100.0 \%$ & $0.01[-0.08,0.10]$ & \\
\hline $\begin{array}{l}\text { Total events } \\
\text { Heterogeneity: } \text { Chi }^{2}= \\
\text { Test for overall effect }\end{array}$ & $\begin{array}{r}92 \\
.42, \mathrm{df}= \\
=0.24(P\end{array}$ & $\begin{array}{l}(P=0.3 \\
0.81)\end{array}$ & $\begin{array}{c}90 \\
I^{2}=12 \%\end{array}$ & & & & 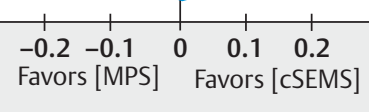 \\
\hline
\end{tabular}

- Fig. 5 Forest Plot of number of strictures resolved.

\section{Discussion}

Treatment of biliary stricture after liver transplantation with CSEMS has aroused interest in follow-up of transplanted patients because traditional protocols with plastic stents have an approximate duration of 1 year and several ERCPs are required to complete treatment. A study with a high level of evidence is still necessary [25], such as this meta-analysis including only RCTs because new randomized trials are available in the literature, two of which $[23,24]$ were published recently (2017). This thereby shows the need for and interest in determining whether CSEMS are adequate and yield results similar to MPSs. All studies included in this systematic review and meta-analysis had adequate randomization and allocation, few losses, and good quality.

As expected, the number of ERCPs was considerably lower in the CSEMS cases because this treatment involves only two procedures, one to place the stent and another to remove it. This result was consistent among studies, and this issue is already considered to be resolved. Therefore, we need to know if fewer ERCPs are associated with lower AE rates, lower costs, and greater patient acceptance.

Similar to the number of ERCPs, duration of treatment was also shorter in the CSEMS cases because most MPS protocols last 1 year and CSEMS protocols last a maximum of 6 months. 


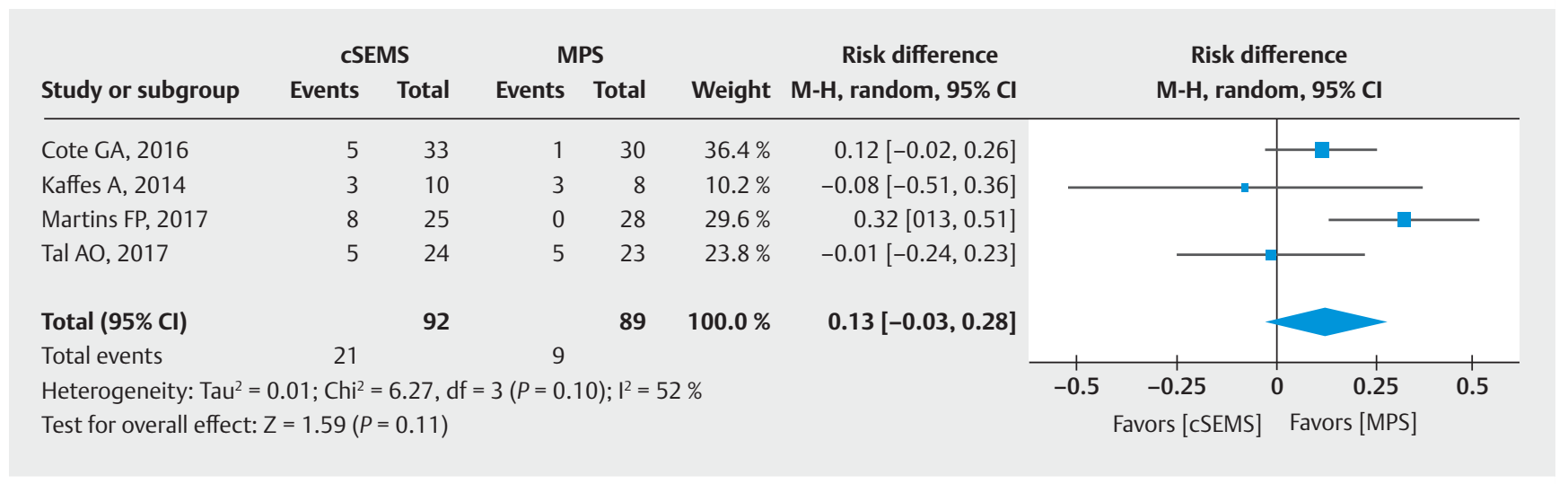

Fig. 6 Forest Plot of stricture recurrence.

\begin{tabular}{|c|c|c|c|c|c|c|c|c|c|}
\hline \multirow{3}{*}{$\begin{array}{l}\text { Study or subgroup } \\
\text { Cote GA, } 2016\end{array}$} & \multicolumn{3}{|c|}{ cSEMS } & \multicolumn{3}{|c|}{ MPS } & \multirow{2}{*}{ Weight } & \multirow{2}{*}{$\begin{array}{l}\text { Mean difference } \\
\text { IV, random, 95\% CI }\end{array}$} & \multirow{2}{*}{$\begin{array}{l}\text { Mean difference } \\
\text { IV, random, } 95 \% \mathrm{Cl}\end{array}$} \\
\hline & Mean & SD & Total & Mean & SD & Total & & & \\
\hline & 158.2 & 89.7 & 37 & 193.5 & 88.7 & 36 & $25.4 \%$ & $-35.30[-76.23,5.63]$ & $\longrightarrow$ \\
\hline Kaffes A, 2014 & 113.2 & 21.6 & 10 & 279 & 77.9 & 10 & $24.8 \%$ & $-165.80[-215.90,-115.70]$ & $\longrightarrow$ \\
\hline Martins FP, 2017 & 139.2 & 66 & 32 & 342.8 & 52.5 & 32 & $26.0 \%$ & $-203.40[-232.62,-174.18]$ & $\rightarrow-$ \\
\hline Tal AO, 2017 & 243.25 & 121.5 & 24 & 252 & 107.7 & 24 & $23.8 \%$ & $-8.75[-73.71,56.21]$ & - \\
\hline Total $(95 \% \mathrm{Cl})$ & & & 103 & & & 102 & $100.0 \%$ & $-105.07[-202.38,-7.76]$ & \\
\hline \multicolumn{9}{|c|}{$\begin{array}{l}\text { Heterogeneity: } \operatorname{Tau}^{2}=9268.49 ; \mathrm{Chi}^{2}=59.80, \mathrm{df}=3(P=0.00001) ; \mathrm{I}^{2}=95 \% \\
\text { Test for overall effect: } Z=2.12(P=0.03)\end{array}$} & $\begin{array}{cccc}-200 & -100 & 0 & 100 \\
\text { Favors [CSEMS] } & \text { Favors [MPS] }\end{array}$ \\
\hline
\end{tabular}

Fig. 7 Forest Plot of treatment time.

\begin{tabular}{|c|c|c|c|c|c|c|c|c|}
\hline \multirow[b]{2}{*}{ Study or subgroup } & \multicolumn{2}{|c|}{ CSEMS } & \multicolumn{3}{|c|}{ MPS } & \multicolumn{2}{|c|}{ Risk difference } & \multirow{2}{*}{$\begin{array}{c}\text { Risk difference } \\
\mathrm{M}-\mathrm{H}, \text { random, } 95 \% \mathrm{Cl}\end{array}$} \\
\hline & Events & Total & Events & Total & Weight & $\mathrm{M}-\mathrm{H}$, random, $95 \% \mathrm{Cl}$ & Year & \\
\hline Kaffes A, 2014 & 1 & 10 & 5 & 10 & $46.8 \%$ & $-0.40[-0.76,0.04]$ & 2014 & $\rightarrow-$ \\
\hline Tal AO, 2017 & 14 & 32 & 9 & 32 & $53.2 \%$ & $0.16[-0.08,0.39]$ & 2017 & -1 \\
\hline Total (95\% CI) & & 42 & & 42 & $100.0 \%$ & $-0.10[-0.65,-0.44]$ & & 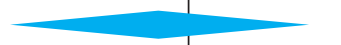 \\
\hline Total events & 16 & & 14 & & & & & \\
\hline \multicolumn{8}{|c|}{$\begin{array}{l}\text { Heterogeneity: } \text { Tau }^{2}=0.13 ; \mathrm{Chi}^{2}=6.53, \mathrm{df}=1(P=0.01) ; \mathrm{I}^{2}=85 \% \\
\text { Test for overall effect: } Z=0.37(P=0.71)\end{array}$} & 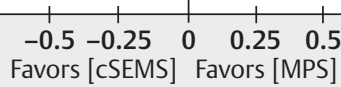 \\
\hline
\end{tabular}

Fig. 8 Forest Plot of adverse events.

Stricture resolution was similar among all studies, with no statistical difference, showing equivalence in initial treatment success between the methods $[10,13,23,24]$. However, as stricture resolution after the initial treatment was determined by cholangiography at time of stent removal, it is not likely to be very informative concerning a relevant clinical endpoint because cholangiography at time of removal is very likely to have improved enough to warrant stent removal.

Recurrence is one of the most debated issues in this topic. Although it appears that the question of stricture resolution has been answered, more information is still needed with regard to recurrence. In this analysis, there was no statistical dif- ference in rates of recurrence. However, the study by Martins et al.[24] was the only one that showed a significantly higher rate of recurrence in the CSEMS group, and the authors raised the hypothesis that the shorter dwelling time of the CSEMS in the bile duct (6 months) was responsible for the rate of recurrence being higher in the CSEMS group than in the MPS group (dwelling time of 12 months) in their study. Although this was not the main objective of their study, Martins et al. [24] followed these patients, and six of the eight patients who had recurrence after CSEMS were successfully treated after a new endoscopic treatment with MPS for 1 year. Cote et al. [10], Martins et al. [24], and Tal et al. [23] clearly indicated a minimum follow-up period 


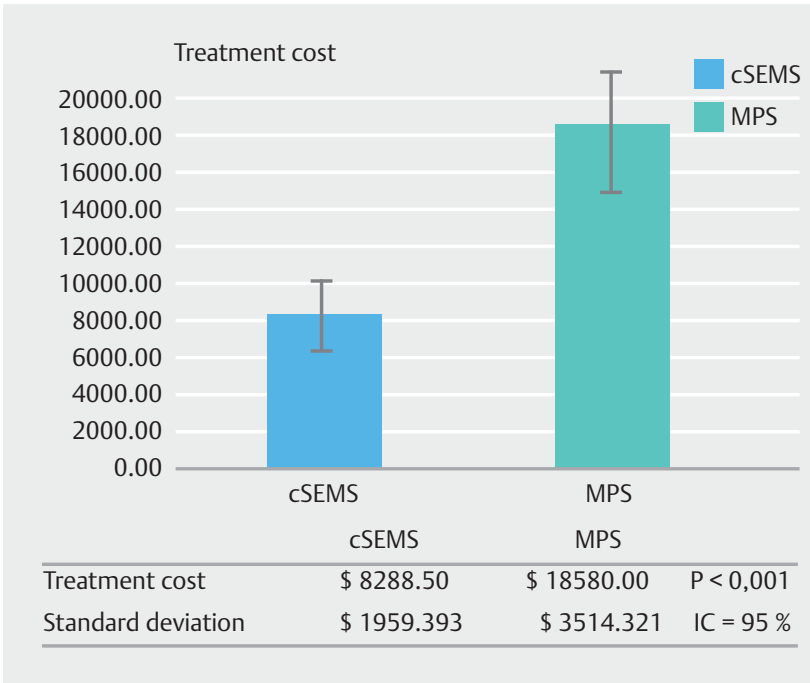

Fig. 9 Graph of the cost means.

of 1 year, whereas Kaffes et al.[13] did not report a minimum follow-up period. Given the benign characteristics of the underlying disease and associated life expectancy, even a follow-up of 12 months is probably not enough to make firm assumptions on long-term efficacy (especially in the CSEMS group because more is known about the chance of recurrence in the MPS group).

Another major concern is stent migration because a totally covered CSEMS would be more likely to migrate, causing AEs and affecting the final outcome of treatment. We did not find statistical significant difference related to migration, but this analysis was performed taking into consideration the number of patients instead of the number of stents used. Kaffes et al. [13] used a specific metallic prosthesis with a larger diameter at the ends, which may have reduced the number of migrations in that study. The different types of stents used may limit overall generalization. Migration of CSEMS does not seem to cause major repercussions: Tal et al. [23] reported eight migrations of CSEMS; four did not present further stricture (among these, one patient had recurrence and was again treated with CSEMS successfully) and the other four that still had stricture crossed over to the MPS group.

Data related to AEs are scarce, and the studies that mention them $[13,24]$ do not clarify whether any patient presented more than one AE. Both procedures are relatively safe and do not have $\mathrm{AE}$ rates that prevent their execution. The rate of pancreatitis after CSEMS decreases considerably when papillotomy is performed, and this procedure is also indicated for deployment of CSEMS [24].

The most unexpected result, which is an argument in favor of use of CSEMS, was related to costs. Treatment with CSEMS was widely believed to be more expensive because of the costs of the stents [23], but the current study showed, via a meta-analysis of two studies on different continents (Kaffes et al. [13] and Martins et al. [24]), that use of CSEMS was consistently advantageous, with a cost that was less than half of that of the
MPS treatment (average of $\$ 8,288.50$ versus $\$ 18,580.00$, respectively; $P<0.001$ ).

One of the limitations was the way each study was analyzed. Martins et al. [24] considered the need for crossover as treatment failure whereas Tal et al. [23] did not consider this as failure and conducted the analysis by intention to treat at the end. However, Tal et al. [23] had a similar number of crossovers in both groups (four crossovers from CSEMS to MPS and three from MPS to CSEMS) and all cases resulted in stricture resolution; therefore, we don't believe that crossover affected the final analysis.

Diagnosis and treatment success were determined by assessment of cholangiography, and none of the studies established a relationship between diagnosis and resolution of biliary stricture and laboratory tests (hepatobiliary enzymes).

The different types of stents used and the 1-year follow-up can reveal unreliable data once it affects the migration rate and recurrence rate.

Data on AEs are scarce, and because some studies reported only some AEs, these could not be comprehensively included in the meta-analysis.

This is the first systematic review and meta-analysis to include only randomized studies on this topic with an adequate number of patients (205). It showed statistical differences with regard to several outcomes, thereby answering several questions related to this topic.

\section{Conclusion}

Rates of resolution and recurrence of biliary stricture after liver transplantation were similar, and the number of ERCPs performed, number of stents used, duration of treatment, and costs were lower in the CSEMS group than in the MPS group. These results show that use of CSEMS is a valid option for initial treatment of post-OLTX anastomotic biliary stricture. Whether it should be standard of care should ideally depend on larger RCTs with adequate follow-up (i.e. 2 years or longer) and one type of stent.

\section{Competing interests}

None

References

[1] Akamatsu N, Sugawara Y, Hashimoto D. Biliary reconstruction, its complications and management of biliary complications after adult liver transplantation: A systematic review of the incidence, risk factors and outcome. Transpl Int 2011; 24: 379-392

[2] Kochhar G, Parungao JM, Hanouneh IA et al. Biliary complications following liver transplantation. World J Gastroenterol 2013; 19: 2841 2846

[3] Nemes B, Gámán G, Doros A. Biliary complications after liver transplantation. Expert Rev Gastroenterol Hepatol 2015; 9: 447-466 
[4] Albert JG, Filmann N, Elsner J et al. Long-term follow-up of endoscopic therapy for stenosis of the biliobiliary anastomosis associated with orthotopic liver transplantation. Liver Transplant 2013; 19: 586-593

[5] Suárez F, Otero A, Solla M et al. Biliary complications after liver transplantation from maastricht category-2 non-heart-beating donors. transplantation 2008; 85: 9-14

[6] Seehofer D, Eurich D, Veltzke-Schlieker W et al. Biliary complications after liver transplantation: Old problems and new challenges. Am J Transplant 2013; 13: 253-265

[7] Kao D, Zepeda-Gomez S, Tandon P et al. Managing the post-liver transplantation anastomotic biliary stricture: Multiple plastic versus metal stents: A systematic review. Gastrointest Endosc 2013; 77 : 679-691

[8] Poley JW, Lekkerkerker MN, Metselaar HJ et al. Clinical outcome of progressive stenting in patients with anastomotic strictures after orthotopic liver transplantation. Endoscopy 2013; 45: 567 - 570

[9] Tringali A, Barbaro F, Pizzicannella M et al. Endoscopic management with multiple plastic stents of anastomotic biliary stricture following liver transplantation: Long-term results. Endoscopy 2016; 48: 546 551

[10] Coté GA, Slivka A, Tarnasky P et al. Effect of covered metallic stents compared with plastic stents on benign biliary stricture resolution. JAMA 2016; 315: 1250

[11] Kahaleh M, Brijbassie A, Sethi A et al. Multicenter trial evaluating the use of covered self-expanding metal stents in benign biliary strictures: time to revisit our therapeutic options? J Clin Gastroenterol 2013; 47: 695-699

[12] Devière ], Reddy DN, Püspök A et al. Successful management of benign biliary strictures with fully covered self-expanding metal stents. Gastroenterology 2014; 147: 385-395

[13] Kaffes A, Griffin S, Vaughan R et al. A randomized trial of a fully covered self-expandable metallic stent versus plastic stents in anastomotic biliary strictures after liver transplantation. Therap Adv Gastroenterol 2014; 7: 64-71

[14] Jiménez-Pérez M, Melgar Simón JM, Durán Campos A et al. Endoscopic management of post-liver transplantation biliary strictures with the use of fully covered metallic stents. Transplant Proc 2016; 48: 2510 2514
[15] Poley JW, Cahen DL, Metselaar HJ et al. A prospective group sequential study evaluating a new type of fully covered self-expandable metal stent for the treatment of benign biliary strictures (with video). Gastrointest Endosc 2012; 75: 783 - 789

[16] Sauer P, Chahoud F, Gotthardt D et al. Temporary placement of fully covered self-expandable metal stents in biliary complications after liver transplantation. Endoscopy 2012; 44: 536 - 538

[17] Tarantino I, Traina M, Mocciaro F et al. Fully covered metallic stents in biliary stenosis after orthotopic liver transplantation. Endoscopy 2012; 44: $246-250$

[18] Liberati A, Altman DG, Tetzlaff J et al. The PRISMA statement for reporting systematic reviews and meta-analyses of studies that evaluate healthcare interventions: explanation and elaboration. BMJ 2009; 339: b2700

[19] Higgins JPT, Green S. Cochrane Handbook for Systematic Reviews of Interventions Version 5.1.0. [updated March 2011] In: The Cochrane Collaboration 2011 Table 7.7.a: Formulae for combining groups

[20] Clark HD, Wells GA, Huët C et al. Assessing the quality of randomized trials: Reliability of the Jadad scale. Control Clin Trials 1999; 20: 448 452

[21] Guyatt GH, Oxman AD, Vist GE et al. GRADE: An emerging consensus on rating quality of evidence and strength of recommendations. Chinese J Evidence-Based Med 2009; 9: 8-11

[22] Hozo SP, Djulbegovic B, Hozo I. Estimating the mean and variance from the median, range, and the size of a sample. BMC Med Res Methodol 2005; 5: 13

[23] Tal AO, Finkelmeier F, Filmann $\mathrm{N}$ et al. Multiple plastic stents versus covered metal stent for treatment of anastomotic biliary strictures after liver transplantation: a prospective, randomized, multicenter trial. Gastrointest Endosc 2017; 86: 1038-1045

[24] Martins FP, De Paulo GA, Contini MLC et al. Metal versus plastic stents for anastomotic biliary strictures after liver transplantation: A randomized controlled trial. Gastrointest Endosc 01 2018; 87: 131.e1 131.e13

[25] Levels of Evidence. Univ Oxford: Oxford Centre for Evidence-based Medicine; 2009: (November 1998) 4-5 www.cebm.net 


\section{-Annex 1 \\ MEDLINE e EMBASE \\ (Liver transplantation OR Hepatic Transplantation OR Liver Grafting OR Hepatic Transplantation) AND (biliary stricture OR biliary stenosis OR biliary stenose OR ercp OR plastic OR metallic OR stent OR cholangiography OR cholangiopan- creatography) \\ Scielo/Lilacs e Cochrane \\ Liver transplantation AND biliary}

- Annex 2 GRADE Summary of Findings for evidence quality

\begin{tabular}{|c|c|c|c|c|c|}
\hline \multirow[t]{2}{*}{ Outcomes } & \multicolumn{2}{|c|}{ Anticipated absolute effects ${ }^{1}(95 \% \mathrm{Cl})$} & \multirow{2}{*}{$\begin{array}{l}\text { Relative } \\
\text { effect } \\
(95 \% \mathrm{Cl})\end{array}$} & \multirow{2}{*}{$\begin{array}{l}\text { № of participants } \\
\text { (studies) }\end{array}$} & \multirow{2}{*}{$\begin{array}{l}\text { Certainty of } \\
\text { the evidence } \\
\text { (GRADE) }\end{array}$} \\
\hline & Risk with MPS & Risk with cSEMS & & & \\
\hline Number of ERCPs & $\begin{array}{l}\text { The mean number } \\
\text { of ERCPs was } 5.75\end{array}$ & $\begin{array}{l}\text { The mean number of ERCPs in the } \\
\text { intervention group was } 1,86 \text { lower } \\
\text { ( } 3,12 \text { lower to } 0,6 \text { lower) }\end{array}$ & - & $\begin{array}{l}205 \\
\text { (4 RCTs) }\end{array}$ & $\begin{array}{l}\otimes \otimes \otimes ० \\
\text { MODERATE }^{2}\end{array}$ \\
\hline Number of stents & $\begin{array}{l}\text { The mean number } \\
\text { of stents was } 12\end{array}$ & $\begin{array}{l}\text { The mean number of stents in the } \\
\text { intervention group was } 10,63 \text { low- } \\
\text { er }(20,82 \text { lower to } 0,44 \text { lower) }\end{array}$ & - & $\begin{array}{l}112 \\
\text { (2 RCTs) }\end{array}$ & $\begin{array}{l}\otimes \otimes \circ ० \\
\text { LOW }^{2,3}\end{array}$ \\
\hline Stricture Resolution & 88 per 100 & $\begin{array}{l}1 \text { per } 100 \\
\text { (-7 to } 9)\end{array}$ & $\begin{array}{l}\text { RD } 0.01 \\
(-0.08 \text { to } 0.10)\end{array}$ & $\begin{array}{l}205 \\
\text { (4 RCTs) }\end{array}$ & $\begin{array}{l}\otimes \otimes \otimes ० \\
\text { MODERATE }{ }^{4}\end{array}$ \\
\hline $\begin{array}{l}\text { Stricture Recur- } \\
\text { rence }\end{array}$ & 10 per 100 & $\begin{array}{l}1 \text { per } 100 \\
(0 \text { to } 3)\end{array}$ & $\begin{array}{l}\text { RD } 0.13 \\
(-0.03 \text { to } 0.28)\end{array}$ & $\begin{array}{l}181 \\
\text { (4 RCTs) }\end{array}$ & $\begin{array}{l}\otimes \otimes \circ ० \\
\text { LOW }^{2,4}\end{array}$ \\
\hline Treatment Time & $\begin{array}{l}\text { The mean treat- } \\
\text { ment Time was } 252 \\
\text { days }\end{array}$ & $\begin{array}{l}\text { The mean treatment Time in the } \\
\text { intervention group was } 105,07 \\
\text { days lower ( } 202,38 \text { lower to } 7,76 \\
\text { lower) }\end{array}$ & - & $\begin{array}{l}205 \\
\text { (4 RCTs) }\end{array}$ & $\begin{array}{l}\otimes \otimes \otimes 0 \\
\text { MODERATE }^{2}\end{array}$ \\
\hline Adverse Events & 33 per 100 & $\begin{array}{l}-\mathbf{3} \text { per } 100 \\
(-22 \text { to } 15)\end{array}$ & $\begin{array}{l}\text { RD }-\mathbf{0 . 1 0} \\
(-0.65 \text { to } 0.44)\end{array}$ & $\begin{array}{l}84 \\
(2 \mathrm{RCTS})\end{array}$ & $\begin{array}{l}\otimes \otimes \circ ० \\
\text { LOW }^{2,5}\end{array}$ \\
\hline
\end{tabular}

CI: Confidence interval; MD: Mean difference; GRADE Working Group grades of evidence: High certainty: We are very confident that the true effect lies close to that of the estimate of the effect, Moderate certainty: We are moderately confident in the effect estimate: The true effect is likely to be close to the estimate of the effect, but there is a possibility that it is substantially different, Low certainty: Our confidence in the effect estimate is limited: The true effect may be substantially different from the estimate of the effect, Very low certainty: We have very little confidence in the effect estimate: The true effect is likely to be substantially different from the estimate of effect

${ }^{1}$ The risk in the intervention group (and its $95 \%$ confidence interval) is based on the assumed risk in the comparison group and the relative effect of the intervention (and its $95 \% \mathrm{Cl}$ ).

2 i $2>50 \%$

${ }^{3}$ Tal et al. considered the crossovers for the measures, while Martins et al. didn't

${ }^{4}$ Absent of endoscopist blindness

${ }^{5}$ Small number of patients included 


\begin{tabular}{|c|c|c|c|c|c|c|c|c|}
\hline \multicolumn{9}{|l|}{ Annex 3} \\
\hline & $\begin{array}{l}\text { Kaffes A, } \\
2014\end{array}$ & & $\begin{array}{l}\text { Cote GA, } \\
2016\end{array}$ & & $\begin{array}{l}\text { Tal AO, } \\
2017\end{array}$ & & $\begin{array}{l}\text { Martins } \\
\text { FP, } 2017\end{array}$ & \\
\hline \multicolumn{9}{|l|}{ Results } \\
\hline & FCSEMS & MPS & FCSEMS & MPS & FCSEMS & MPS & FCSEMS & MPS \\
\hline Patients & 10 & 10 & 37 & 36 & 24 & 24 & 32 & 32 \\
\hline Number of ERCPs & $\begin{array}{l}2.0 \\
(2.0-2.0)\end{array}$ & $\begin{array}{l}4.5 \\
(2.0-6.0)\end{array}$ & $\begin{array}{l}2,21 \\
( \pm 0,48)\end{array}$ & $\begin{array}{l}3,13 \\
( \pm 0,88)\end{array}$ & $\begin{array}{l}2.0 \\
(2.0-12.0)\end{array}$ & $\begin{array}{l}4.0 \\
(3.0-12.0)\end{array}$ & $2(2-2)$ & $5(4-6)$ \\
\hline $\begin{array}{l}\text { Number of stents } \\
\text { per patient }\end{array}$ & & & & & $\begin{array}{l}1.0 \\
(1.0-24.0)\end{array}$ & $\begin{array}{l}8.0 \\
(2.0-32.0)\end{array}$ & $1(1-1)$ & $16(6-30)$ \\
\hline Stricture resolution & 10 & 8 & 34 & 34 & 24 & 23 & 25 & 28 \\
\hline $\begin{array}{l}\text { Stricture recur- } \\
\text { rence }\end{array}$ & $3 / 10$ & $3 / 8$ & $5 / 33$ & $1 / 30$ & $5 / 24$ & $5 / 23$ & $8 / 25$ & $0 / 28$ \\
\hline $\begin{array}{l}\text { Treatment time } \\
\text { (median/range) }\end{array}$ & $\begin{array}{l}3.8 \\
(2.5-5.0) \\
\text { months }\end{array}$ & $\begin{array}{l}10.1 \\
(4.0-13.0) \\
\text { months }\end{array}$ & $\begin{array}{l}158.2 \\
( \pm 89,7)\end{array}$ & $\begin{array}{l}193.5 \\
( \pm 88.7)\end{array}$ & $\begin{array}{l}178.5 \\
(65-551)\end{array}$ & $\begin{array}{l}229.5 \\
(59-490)\end{array}$ & $\begin{array}{l}158,5 \\
(9-239)\end{array}$ & $\begin{array}{l}354 \\
(222-42)\end{array}$ \\
\hline Adverse events & $\begin{array}{l}1 \text { (cholan- } \\
\text { gitis) }\end{array}$ & $\begin{array}{l}5 \text { ( } 4 \text { cho- } \\
\text { langitis, } \\
1 \text { pain) }\end{array}$ & & & & & $14 / 60$ & $9 / 141$ \\
\hline Migration & 0 & 1 & & & & & $3 / 30$ & $4 / 141$ \\
\hline Cost & $\begin{array}{l}\text { AUD: } \\
10830,00 \\
\text { (USD: } \\
9674,00)\end{array}$ & $\begin{array}{l}\text { AUD: } \\
23580,00 \\
\text { (USD: } \\
21065,00 \text { ) }\end{array}$ & & & & & $\begin{array}{l}\text { USD: } \\
6903,00\end{array}$ & $\begin{array}{l}\text { USD: } \\
16095,00\end{array}$ \\
\hline
\end{tabular}

